\title{
Satellite survey of seasonal trophic status and occasional anoxic 'malaigue' crises in the Thau lagoon using MERIS images
}

\author{
Minghelli-Roman Audrey ${ }^{1, *}$; Laugier Thierry ${ }^{2}$; Polidori Laurent ${ }^{3}$; Mathieu Sandrine ${ }^{4}$; Loubersac \\ Lionel $^{2} ;$ Gouton Pierre ${ }^{1}$
}

${ }^{1}$ LE2I, Universite de Bourgogne, UMR-CNRS 5158, Dijon Cedex, France

2 LER/LR, Ifremer, Bd Jean Monnet, BP 171, Sete Cedex, France

${ }^{3}$ CNAM, ESGT, 1, Boulevard Pythagore - Campus Universitaire, Le Mans, France

${ }^{4}$ Thales Alenia Space, Cannes la Bocca Cedex, France

*: Corresponding author : Minghelli-Roman Audrey, email address : aroman@u-bourgogne.fr

\begin{abstract}
:
The Thau lagoon, located in southern France, suffers episodically from anoxic crises locally known as 'malaigue'. Such crises mostly occur under warm conditions, low winds leading to a strong eutrophication of the lagoon. The development of a sulphur bacterium sometimes gives locally to the waters a 'milky turquoise' appearance and leads to shellfish mortality. One of the indicators of the eutrophication status of the lagoon can be surveyed by the chlorophyll product provided by remote sensing images such as Medium Resolution Imaging Spectrometer (MERIS). In this paper we compare chl2 (or algal2) estimations provided by MERIS level 2 products and the ground measurements of chlorophyll a concentrations in water and we propose a linear correction of the chl2 MERIS product. The corrected chl2 estimations obtained over four years are analysed to understand the seasonal evolution of the trophic status of the Thau lagoon. We also study the influence of the anoxic crises of summers 2003 and 2006 on the chl2 estimations and we find a strong correlation between chl 2 and the oxygen percentage at $1 \mathrm{~m}$ depth (0.70 for measurements in summers 2003 and 2006).
\end{abstract}




\section{Introduction}

A review of literature pertaining to ecological effects of hypoxia and anoxia revealed that the oxygen budgets for many ecosystems around the world have been adversely affected mainly through the process of eutrophication. Eutrophication produces excess organic matter that fuels the development of hypoxia and anoxia when combined with water column stratification. Many ecosystems have reported some type of monotonic decline in dissolved oxygen levels through time with a strong correlation between human activities and declining dissolved oxygen (Diaz, 2001, Rowe, 2001, Ellegaard et al. 2006);

When large quantities of nitrogen and phosphorus get into water, they trigger the excessive growth of microscopic algae, called phytoplancton. Then, these die, drop to the bottom and cause the proliferation of aerobic bacteria, which in turn consume large quantities of oxygen. When this happens in waters, where stratification is a tendency, deep water oxygen levels fall to $2 \mathrm{ml} \mathrm{l}^{-1}$ of sea water, or less. This situation is called hypoxia.

The western French Mediterranean coast is bordered by several shallow lagoons formed during the later stages of the Holocene transgression. These lagoons, located in a densely populated zone, between the continent and the sea, are fragile ecosystems which have been, and still are, heavily impacted by human activity. These lagoons suffer from eutrophication as a result of excessive nutrient inputs from catchments, very low water renewal (flushing time is about 3 months) and specific climate conditions (high temperature and insolation, limited rainfall periods, low tidal currents).

The Thau lagoon, one of the largest lagoons of the French Mediterranean, is the site of intensive shellfish farming. It is a shallow lagoon, $19.5 \mathrm{~km}$ long and $4.5 \mathrm{~km}$ wide with a mean depth of $4 \mathrm{~m}$. The lagoon is almost closed, with only one narrow opening toward the sea. Its 
catchment basin is about $300 \mathrm{~km}^{2}$, including agriculture, industrial activities and urban waste. All these activities including aquaculture in the lagoon interfere on the lagoon water quality, sometimes leading to dystrophic crises called "Malaigue". The shellfish farming zones cover $1 / 5$ of the lagoon surface area with an annual production of 30,000 tonnes. This production is made according to an original technique of binding oysters (or mussels) on ropes, themselves fixed on metallic structures (tables). Then the continuous immersion of oyster-mussel ropes involves an abundant epibiotic development. The presence of these heterotrophic organisms (epibiose) in the water column modifies the transfer and the transformation of the organic matter within the lagoon ecosystem (Mazouni et al. 1996, 1998). The combination of high organic matter production, high summer temperature $\left(25^{\circ} \mathrm{C}\right.$ water surface temperature) and low wind speed induces the eutrophication of the lagoon and sometimes the rapid depletion of dissolved oxygen and subsequent anoxia (Harzallah et al. 2002). Anoxic conditions develop in summer both at the sediment-water interface in deep zones and/or at the edges of the lagoon. These anoxic episodes induce a high turbidity and hydrogen sulphide release during the summer months with a heavy mortality of organisms, among which farmed shellfish.

As the chlorophyll concentration is directly linked to eutrophication, we have compared the satellite chlorophyll estimations to local measurements in order to provide regular and consistent maps as frequently as the satellite can provide images. The advantages provided by satellite images are temporal regularity and spatial coverage with minimal local measurements.

The anoxic crises of summer 2003 and summer 2006 has been surveyed weekly by the laboratory LER/LR (Laboratoire Environnement Ressourcel Languedoc Roussillon) of 
Ifremer because the previous anoxic crisis of summer 1997 had inflicted major damage to the shellfish economy (death of one third of the annual product).

In the case of an anoxic event, there is a release of reduced (mainly sulphide) in the water column (due to anaerobic sulphate reduction in surface sediments). These reduced sulphur compound inputs lead to the development of a phototropic bacteria community which reoxydises these reduced compounds (Guyoneaud et al., 1998; Pringault et al., 1998). These sulphur bacteria may either belong to the Chromatiaceae family (leading to red waters) or to the Chlorobiaceae family (leading to white waters). In fact, the white colour is due to temporary accumulation of sulphur particles within the bacteria cells (Souchu et al, 1998; Anschutz et al., 2007; Dedieu et al., 2007). As in the observations made by Weeks et al. (2002) on the coast of Namibia, here, the process leading to the water "milky turquoise" appearance is related to sulphur biochemistry and comes from hypoxia conditions. The difference between the two observations is that in the Thau lagoon the re-oxydation of sulphur is a biological process.

The colour of water has been studied since the first images of remote sensing. The Coastal Zone Colour Scanner (CZCS), launched in 1978 provided 8 years of data. The algorithms of chlorophyll concentrations have allowed a better understanding of ocean primary production quantitatively and geographically (Morel, 1988). Upwellings on west coasts of continents were then observed but the spatial resolution of CZCS (800 m) and the spectral resolution (6 bands) limited its applications to case- 1 waters. More complex, coastal and inland waters required novel processing. The successor of CZCS, Sea-viewing Wide Field-of-view Sensor (SeaWiFS), launched in 1997, also had a limited resolution of $1100 \mathrm{~m}$ (Deschamps and Viollier, 1987). Since 2002, MEdium Resolution Imaging Spectrometer (MERIS) has 
provided images with a $300 \mathrm{~m}$ resolution and 15 spectral bands. These features become more relevant for coastal or inland waters eutrophication studies for example (Schiller and Doerffer, 1999). But in case-2 waters, the reflectance is not only influenced by the chlorophyll concentration. Suspended matter and coloured dissolved organic matter but also the reflectance of the seabed in shallow waters, modify the sea surface reflectance (Sathyendranath et al., 1989, and Maritorena et al., 1994). Coastal and inland waters are typically case 2 waters and have optical conditions varying widely from those of open ocean case 1 waters.

Algorithms based on model inversion (Forget et al., 1999) or neural networks (Schiller and Doerffer, 1999) take into account these new influences and provide an estimation of the concentration of chlorophyll and/or suspended matter in coastal waters. MERIS level 2 data provide validated products of algal, suspended matter and yellow substance for case- 1 and case-2 waters. However, MERIS level 2 products must still undergo thorough regional validation, particularly in complex waters prone to additional contributions from mineral, dissolved matter and/or bottom reflectance.

In the literature some studies deal with the evaluation of the water quality in lagoons or lakes with remote sensing data. Vos et al. 2003, for lakes IJssel and Marken (Netherland), develop their own model based on band ratio to convert the reflectances of Sea-viewing Wide Fieldof-view Sensor (SeaWiFS) images into chlorophyll concentrations with an accuracy of 30\%. Zilioli and Brivio (1997), for lake Garda (Italy), develop a qualitative indicator of eutrophication based on chromaticity parameters. Concerning MERIS products, validation studies carried out in Constance lake (Gege et Plattner, 2003) have reported a mean error of $0.01 \mathrm{mg} \mathrm{m}^{-3}$ for the chlorophyll estimation of chl2 product. But Constance Lake is much 
larger and deeper than the Thau lagoon and this may foretell a higher chlorophyll estimation error in the Thau Lagoon.

In Mediterranean coastal lagoons, especially in the Thau lagoon, chlorophyll $a$ (chl $a$ ) is a rather good indicator of eutrophication. Of course, several other biological indicators could be used to evaluate the level of eutrophication (e.g. benthic flora and fauna shift, total nitrogen and phosphorus in water column...). Water chl $a$ concentration was determined and validated to be a good integrated indicator for eutrophication and is used in a monitoring program of Mediterranean coastal lagoon eutrophication (http://rsl.cepralmar.com).

In this paper, we present the potential of MERIS images to survey the trophic status of the Thau lagoon in order to monitor the onset of eutrophication and anticipate the occurence of an anoxic event. The influence of the anoxic crises of 2003 and 2006 on these images is also analysed.

\section{Material and methods}

\subsection{Site}

The Thau lagoon is located on the French Mediterranean coast in the vicinity of the city of Sète. It is a shallow lagoon with a mean depth of $4 \mathrm{~m}$ and an area of $75 \mathrm{~km}^{2}$ (Chapelle, et al. 2000). The lagoon is a semi-confined ecosystem, with two sea water inlets and several river inputs. Only two of them are permanent (La Vène and Pallas rivers). Thermal and karstic groundwater also contributes to freshwater input (Aquilina et al., 2002). The catchment basin is about $300 \mathrm{~km}^{2}$ and the average water residence time is about 3 months (Millet, 1989). Tidal range is mostly less than half a meter. Currents are principally driven by dominant winds from 
the North and North-West regularly blowing at $10 \mathrm{~ms}^{-1}$, and rising several times a year to more than $30 \mathrm{~ms}^{-1}$. Wind speeds of $10 \mathrm{~ms}^{-1}$ generate current velocities close to $10 \mathrm{~cm} \mathrm{~s}^{-1}$ in the entire water column (Lazure, 1992). Shellfish farming areas cover about 1/5 of the lagoon area. The density of shellfish tables strongly limits water circulation (by a factor of 3) and is clearly one of the expansion factors of anoxic events (Chapelle et al., 2000). Shellfish activity generates important biodeposits (about $500 \mathrm{~kg} \mathrm{ha}^{-1} \mathrm{yr}^{-1}$, De Casabianca et al. 1997).

\subsection{Images}

The images used in this study are MERIS level 2 images. As these images are corrected for atmospheric effects, each pixel is expressed as percentage above water reflectance. This level processing is also retained because images contain products like maps of chlorophyll and suspended matter. These products have been generated by algorithms based on spectral band ratio (case 1, Antoine and Morel, 1999) and neural network (Schiller and Doerffer, 1999). The spatial image resolution is 300 m with 13 spectral bands (2 of the 15 original bands have been used for atmospheric corrections). The revisit period of 3 days, due to the wide swath (1100 $\mathrm{km}$ ), allows the survey of phenomena with high temporal variability. For MERIS level 2 images, we noticed that "black pixels" were located on land/water boundaries. Santer and Schmechtig (2000) describe atmospheric corrections as a critical task in the interpretation of ocean colour imagery. In coastal areas, a fraction of the light reflected by the land reaches the sensor (adjacency effect). A sensitivity study indicates that the decisive criterion for accurate measurement of aerosols is their vertical distribution. As this distribution cannot generally be determined from space, it is not possible to include a suitable correction of the adjacency effects on satellite imagery. The mixed pixels on land/water boundaries are then not corrected for atmospheric effect and the reflectance of these pixels is set to zero for all spectral bands in MERIS level 2 images. 
The image database obtained in the framework of the ENVISAT research project (project AOE.822) contains 50 MERIS images acquired between August 2002 and August 2006 (table I). Sometimes, several images per month were available and sometimes none because of bad meteorological conditions. We ordered one per month when it was possible to analyse the seasonal cycles.

Images were processed under ENVI software with some routines developed with IDL language.

\section{[insert table I about here]}

In August 2003 and July 2006 several images were ordered to analyse the anoxic crises in temporal image series.

\subsection{Water measurements}

Since 2000, the RSL lagoon monitoring network (Réseau de Suivi Lagunaire) has supported the management of the lagoon environments in the Languedoc-Roussillon region and developed knowledge about them. Every year, a diagnosis is made of the lagoons' condition, in order to assess the level of eutrophication common to all Mediterranean lagoons for the application of the Water Framework Directive.

The parameters measured annually during June, July and August in the lagoons are: temperature, salinity, turbidity, dissolved oxygen, nitrate, nitric oxide, ammonium, phosphates and chlorophyll. The interpretation method based on thresholds for all measured parameters determines 5 status of eutrophication: very good, good, medium, poor and bad. There are 35 measurement locations in the lagoon. Each year, the RSL lagoon monitoring network publishes the eutrophication maps. The internet site (http://rsl.cepralmar.com/bulletin.html) publishes the maps from 2000 to 2004. On the map of 2003, different trophic levels are 
indicated within the Thau lagoon by coloured points: 3 green points ("good eutrophication status"), 2 yellow points ("medium eutrophication status”) and 1 orange point ("poor eutrophication status"). The orange point in situated in the area of Mèze (centre north of the lagoon).

In periods of anoxic crises like 2003 and 2006, these parameters are measured every week by the laboratory LER/LR of Ifremer together with other parameters like sub-surface $(-1 \mathrm{~m})$ and bottom oxygen saturation, and wind conditions (fig.1 : stars for 2003 and circles for 2006).

[insert Figure 1 about here]

Concerning chlorophyll measurement, the lagoon waters were sampled (2 l) monthly at subsurface level (-1 m) at several sampling stations. Upon return to the laboratory, $50 \mathrm{ml}$ were filtered under a vacuum less than $13.3310^{3} \mathrm{~Pa}$ on Whatman GF/F membranes $(0.7 \mu \mathrm{m}$ porosity) and stored at $-20^{\circ} \mathrm{C}$ in glass tubes (Aminot and Kerouel, 2004). Filters were ground in acetone (90\%) and extracted during $24 \mathrm{~h}$ in the dark at $4^{\circ} \mathrm{C}$. Pigments were measured by spectrofluorimetry (Neveux and Lantoine 1993). Concentrations are expressed in $\mathrm{mg} \mathrm{m}^{-3}$ with an accuracy of $5 \%$.

\subsection{Study of remote sensing image potential}

\section{$\underline{\text { Validation of the chlorophyll product }}$}

Before using the chlorophyll estimations provided by MERIS images, we compared some of these values with ground measurements acquired at 6 different stations in the Thau lagoon between August 2002 and August 2006. Because the number of images was limited to one per 
month, only 88 measurements among the 177 acquired were retained for comparison. The selection criterium was a maximum of 5 days between image acquisition and ground measurement but for $83 \%$ of the values we compared, the lag was under 3 days. Moreover, during summer, chl $a$ dynamics in lagoon waters is mainly driven by benthic nutrient release and microbial loop in the water column, so that a 5 day frequency of measurement captures the chl $a$ dynamics correctly (Chapelle et al. , 2000).

The comparison was carried out for the chlorophyll products of MERIS level 2 (chl2) provided by a neural network (Schiller and Doerffer, 1999) where the chlorophyll concentrations are given in $\mathrm{mg} / \mathrm{m}^{3}$. The first comparison was made between chl2 values and the ground measurements. The error was calculated by means of RMSE. A correction needed to be applied to the product values in order to fit the ground measurement. The data set was split in two. The correction was calculated from one data set and tested independently on the other in terms of RMSE.

\section{Seasonal cycle}

The 50 MERIS level 2 images have been used to analyse the seasonal cycle of eutrophication in the Thau lagoon. Secondly the chl2 product provided in MERIS level 2 processing has been thresholded to give 5 classes to be compared to the RSL eutrophication maps. These thresholds have been defined by experts of Ifremer who twice a month measure the chlorophyll $a$ concentrations in the lagoons (triangles in fig. 1). These thresholds are detailed in Table II.

[insert table II about here] 


\section{$\underline{\text { Anoxic crises }}$}

Two anoxic crises have been analysed on reflectance images and chlorophyll products. This information has also been compared to subsurface ( $-1 \mathrm{~m})$ dissolved oxygen concentrations for the same geographic points at different dates. Six MERIS images were acquired during the anoxic crisis of summer 2003 (9, 12, 19, 22 August and 13, 19 September 2003) and 5 during the anoxic crisis of summer 2006 (10, 121720 and 24 july 2006). In 2003 and 2006 the ground measurements were located differently. In 2003, there were 8 comparison points, represented by stars on fig. 2 and located close to the border in the Mèze area. In 2006, there were 22 comparison points represented by circles (fig. 1).

\section{Results}

\section{$\underline{\text { Validation of the chlorophyll product }}$}

The comparison of the 88 ground measurements with the MERIS level 2 products (chl2) gives a RMSE of $8.47 \mathrm{mg} / \mathrm{m}^{3}$. The error is quite large but we found a consistent linear transform between chl2 and ground measurements (fig. 2). The data set has been split in two. The first data set includes measurements acquired between 19 July 2004 and 19 August 2004 and the second data set corresponds to measurements acquired between 23 August 2004 and 21 August 2004. The linear correction has been calculated from the first data set (19 July 2004 and 19 August 2004) with a slope at 0.2092 and a y-intercept at $1.8118 \mathrm{mg} \mathrm{m}^{-3}$ with a coefficient of determination $R^{2}=0.601$. This correction applied to the second data set gives a RMSE of $1.98 \mathrm{mg} \mathrm{m}^{-3}$ between the chl2 corrected estimation and the ground measurements. This positive intercept of $1.8118 \mathrm{mg} \mathrm{m}^{-3}$ will induce a strong positive bias at low concentrations but it is not significant for eutrophication maps. Table 2 shows that for water containing less than $5 \mathrm{mg} \mathrm{m}^{-3}$ of chlorophyll the trophic status is considered as "very good". 
The weak RMSE after correction confirms the consistency, the necessity and time-stability of chl2 correction in the Thau lagoon.

[insert Figure 2 about here]

\section{$\underline{\text { Seasonal cycle }}$}

A temporal analysis of the trophic status of the Thau lagoon can be carried out by plotting the corrected chl2 product of the MERIS images received over 4 years and the chlorophyll measurements acquired simultaneously (fig. 3). These measurements correspond to different locations in the lagoon indicated by triangles in fig. 1 but for each date, only one location has been represented to make the plot easier to read. Not all locations have been recorded for each date. This explains why different locations have been used for this plot.

[insert Figure 3 about here]

The several peaks correspond to the summer chlorophyll increase which occurred in August 2003, June, July and August 2004, June 2005 and July 2006.

For seasonal survey, and spatial analysis, chl2 corrected maps can be simplified according to table II thresholds (fig.4). These maps can then be compared to the eutrophication map proposed by the RSL survey. Compared to these annual maps, the monthly chl2 corrected maps enable to study the seasonal evolution of the trophic status. Secondly, each pixel provides qualitative information on the trophic status, which is interesting for a spatial understanding of the phenomenon.

[insert Figure 4 about here] 
These maps show a good eutrophication status in winter, spring and autumn and a noticeable degradation in summer due to the rise of the water temperature. But these maps also show that the eutrophication is mainly located on the border with the sea. This can be due to the natural vegetation growing on the borders of the lagoon, or to the very shallow waters.

\section{$\underline{\text { Anoxic crisis }}$}

The 6 colour composites obtained with true colour bands 2, 5 and 7 of MERIS level2 images (442, 560 and $665 \mathrm{~nm}$ ), show that MERIS radiometry is effectively sensitive to increased particule scattering due to the sulphur bacteria during the Malaïgue event. In 2003, no measurement was made concerning bacteria and sulphur but Souchu et al. (1998) analysed water samples containing bacteria and sulphur in 1994 during a similar anoxic event.

Fig. 5 shows the evolution of the phenomenon in August and September 2003.

[insert Figure 5 about here]

On the 12th of August 2003, a first "milky turquoise" spot appeared in the area of Mèze (centre north of the lagoon). This spot has spread to the south-west of Marseillan on the image of 19 August 2003. On 22 August 2003, the Malaïgue reached its paroxysm and then decreased at the end of August. On 19 September 2003, the "milky turquoise” colour disappeared but water chlorophyll concentration remained high as a consequence of this anoxic event.

The spectral profiles of a pixel located at the centre of the "milky turquoise" spot and another one located in the safe part of the lagoon (August 22 2003, fig.5) have been compared in order to characterize the spectral influence of the phenomenon (fig. 6). 


\section{[insert Figure 6 about here]}

Figure 6 presents a very clear spectral signature indicative of chlorophyll bearing biota, with chlorophyll absorption being clearly visible at $670 \mathrm{~nm}$ and $<500 \mathrm{~nm}$. This is an intense bloom of a chlorophyll-containing organism leading to high scattering, giving the waters a "milky turquoise” appearance as referred to in the paper by Weeks et al (2002).

The significant increase of chlorophyll from July to September 2003 and in July 2006 (fig. 3) has also been compared with the oxygen simultaneously measured at $1 \mathrm{~m}$ depth in the Mèze area by the RSL survey (fig. 7).

[insert Figure 7 about here]

Figure 7 shows a high correlation $\left(\mathrm{R}^{2}=0.70\right)$ between the increase of chlorophyll estimation and the decrease of oxygen at $1 \mathrm{~m}$ depth in 2003 and 2006. We can note that the relation between chl2 and oxygen seems to be consistent and stable between 2003 and 2006.

\section{Discussion}

\section{Validation of the chlorophyll product}

The results showed that the chlorophyll estimations needed to be corrected because the estimation algorithm was not initialised on the Thau lagoon. We then try to explain the differences between the chlorophyll estimations and local measurements.

Case 1 waters are those whose optical properties are determined by phytoplankton and their correlated by-products. In contrast, case 2 waters are those where the optical properties are 
determined by additional colour-producing agents such as mineral sediments and/or CDOM that may not correlate with chlorophyll or with each other.

The algorithm giving chl2 is a neural network developed to derive the concentration of phytoplankton pigments, suspended matter and gelbstoff (dissolved organic matter) from turbid coastal waters (case 2 waters). The neural net was parameterised with the Inherent Optical Properties (IOPs) absorption (a) and scattering (b) of these optically active substances. IOPs are variable in time and space (Bricaud et al., 1995), and IOPs in Thau lagoon are likely to differ from the ones used for initialization of the neural net. Another problem can be the standard atmospheric correction of the level-2 products, which can be insufficient in the coast zone where land and water aerosols mix and adjacency effects occur. These reasons can explain the difference here between chl2 and ground measurements and their high correlation. Here the high RMSE obtained before correction can also be explained by 3 specific factors of this region: the first factor is the lagoon bottom whose reflectance can influence the surface reflectance, especially in shallow zones (mean depth of $4 \mathrm{~m}$ ) and in case of high water transparency, that is during the period of low water chlorophyll concentrations (mean attenuation of $0.4 \mathrm{~m}^{-1}$ ). The second factor is the benthic submersed vegetation which grows in very shallow waters around the lagoons and may play a part in the estimation of chl2. That is also why the RMSE is higher for points located close to the lagoon borders. The last factor is that in case of anoxic crises, chlorophyll is not the only factor of reflectance change. The increase of water scattering induces a reflectance change which increases the chlorophyll estimation. But after linear correction, the RMSE is reduced from 8.47 to $1.98 \mathrm{mg} \mathrm{m}^{-3}$.

Before the corrections, the RMSE value excluded the use of estimated chl2 for the trophic status description that uses the thresholds in table II. After correction the RMSE is better for classes "Medium” to "very bad" but uncertainties may persist between classes "very good" 
and "medium". The acquisition of other images and in situ data could then lead to improving the correction and to a lower RMSE, sufficient for an ecological application. The best RMSE should equal $0.5 \mathrm{mg} \mathrm{m}^{-3}$ to obtain reliable maps.

The correction seems to be time stable between 2002 and 2006. A validation on other sites would be necessary before applying this correction anywhere else. This correction could be valid on other close lagoons but it requires to be checked.

\section{$\underline{\text { Seasonal cycle }}$}

Figure 3 shows the fluctuations of corrected chl2 over 4 years in the Thau lagoon . This graph clearly shows the eutrophication process in summer (in 2003, 2004, 2005 and 2006). The chl2 corrected plot clearly follows the chlorophyll measurements (dotted line). Therefore, some weak concentrations (lower than $2 \mathrm{mg} \mathrm{m}^{-3}$ ) are sometime overestimated. This side-effect was mentioned before but is weak enough to be ignored.

For clarity reasons only one point for any one date has been plotted but sometimes chlorophyll has been measured for the 6 triangles (fig. 1) with a range from 1 to $9 \mathrm{mg} \mathrm{m}^{-3}$ in the Thau lagoon. This range shows that the eutrophication is not homogeneous all over the lagoon and this information confirms the advantage of spatial information provided by MERIS and justifies its use. Even if some pixels around the lagoon should be excluded because they are mixed or contain shallow water vegetation, each pixel located at different points in the lagoon can be plotted to analyse its temporal evolution. If a general trend is required, the chl2 corrected can be averaged and thresholded to obtain a general trophic status. 
We can also note on this graph that the chlorophyll is always under $4 \mathrm{mg} \mathrm{m}^{-3}$ in winter, autumn and spring and the trophic status is only degraded in summer, reaching $8 \mathrm{mg} \mathrm{m}^{-3}$ and sometimes more (summer 2006). A threshold alarm could be fixed to anticipate anoxic crises.

\section{$\underline{\text { Anoxic crises }}$}

Figure 5 clearly shows the location of the "Malaigue" start and its spatial and temporal evolution between August and September 2003 and how the "Malaigue" diffused in the lagoon. MeRIS images allow to analyse how the increase of water scattering affects the spectral reflectance of the water in 13 spectral bands. This sequence can be of high interest as it would spare renting a plane to take pictures. The satellite then provides a general and repetitive view (under good meteorological conditions).

The relation found between chl2 and oxygen may be a surprise because the low oxygen concentration is here correlated with a high concentration of chlorophyll. Phytoplankton is usually an oxygen producer, so the slope should then be positive. But after the excessive increase of phytoplankton, the microscopic algae die and fall onto the lagoon bottom, leading to the proliferation of bacteria which consume all the oxygen. This explains the negative slope of the plot in figure 7 .

The consistency and the stability of the relation between oxygen and chl2 between 2003 and 2006 is encouraging to use chl2 indirectly from the satellite to get information about oxygen 
percentage at $1 \mathrm{~m}$ depth. This relation should be studied for lower chl2 concentrations in the future.

\section{Conclusion}

This paper has shown that MERIS imagery can be used for the survey of the lagoon trophic status all along the year but also in case of anoxic crises. The chl2 (or algal2) product, corrected by a linear function, is an efficient qualitative indicator of eutrophication. The correction was necessary because the neural net was not initialised on the Thau lagoon and the reasons that caused differences were found. The chlorophyll corrected product has then been used to study the seasonal trophic cycle of the Thau lagoon between summer 2002 and summer 2004. The influence of the Malaigue on the reflectance has been shown by a sequence of 6 images during the crisis of 2003. This work could be used to better survey the evolution of spatial and temporal parameters in the eutrophication process and could help to model and to set up anticipation systems.

\section{Acknowledgment}

We are grateful to the European Space Agency for providing the ENVISAT data used in this study (project AOE.822). 


\section{References}

Aminot A. and Kerouel R., 2004. Hydrologie des écosystèmes marins : paramètres et analyses. Ifremer Eds, 336 p.

Anschutz P., Chaillou G. and Lecroart P., 2007. Phosphorus diagenesis in sediment of Thau lagoon. Estuarine Coastal and Shielf Science, 72, 447-456.

Antoine D. and Morel A., 1999, A multiple scattering algorithm for atmospheric correction of remotely sensed ocean colour (MERIS instrument): principle and implementation for atmospheres carrying various aerosols including absorbing ones, International Journal of Remote Sensing, 20, 1917-1927.

Aquilina L. Ladouche B., Doerfliger N, Seidel J.L., Bakalowicz M., Dupuy C. and Le Strat P., 2002, Origin evolution and residence time of saline thermal fluids (Balaruc springs, southern France): implications for fluid transfer across the continental shelf, Chemical geology, 192, 1-21.

Bricaud, A., Babin, M., Morel, A. and Claustre H., 1995, Variability in the chlorophyllspecific absorption coefficient of natural phytoplankton : analysis and parametrization, Journal of Geophysical Research, 100, C7, 13321-13332.

Chapelle A., Menesguen A., Deslous-Paoli J.M., Souchu P., Mazouni N., Vaquer A. and Millet B., 2000, Modelling nitrogen, primary production, and oxygen in a mediterranean lagoon. Impact on oyster farming and inputs from the watershed, Ecological Modelling, 127, 161-181.

Diaz R.J., Overview of hypoxia around the world, 2001, Journal of environment quality, 30, 275-281 
De Casabianca M.L., Laugier T.and Marinho-Soriano E., 1997, Seasonal changes of nutrients in water and sediments in a Mediterranean lagoon with shellfish farming activity (Thau lagoon, France), ICES Journal of Marine Sciences, 54, 905-916.

Dedieu K., Rabouille C., Gilbert F., Soetaert K, Metzger E, Simonucci C, Jezequel D, Prevot F, Anschutz P, Hulth S, Ogier, S and Mesnage V., 2007. Coupling carbon, nitrogen and oxygen cycle in sediments from a Mediterranean lagoon : a seasonal perspective. Marine Ecology Progress Series, 346, 45-59.

Deschamps P.Y. and Viollier M., 1987, Algorithms for ocean colour from space and application to CZCS, Advances in Space Research, 7, 11-19.

Ellegaard M., Clarke A.L., Reuss N., Drew S., Weckstrom E., Juggins S., Anderson N.J., and Conley D.J., 2006, Multi-proxy evidence of long-term changes in ecosystem structure in a Danish marine estuary, linked to increased nutrient loading, Estuarine, Coastal and Shelf Science, 68, 567-578

Forget P., Ouillon S. , Lahet F. and Broche P., 1999, Inversion of reflectance spectra of non chlorophyllous turbid coastal waters, Remote Sensing of Environment, 68, 264-272.

Gege P. and Plattner S., 2003, MERIS validation activities at lake Constance in 2003, Proceedings MERIS user workshop, Frascaty Italy, 10-13 November 2003

Guyoneaud R., De Wit R., Matheron R. and Caumette, P., 1998. Impact of macroalgal dredging on dystrophic crises and phototrophic bacterial blooms (red waters) in a brackish coastal lagoon Oceanologica Acta, 21 (4), 551-561. 
Harzallah A. and Chapelle A., 2002, Contribution of climate variability to occurrences of anoxic crises 'malaigues’ in the Thau lagoon (southern France), Oceanologica Acta, 25, 79-86.

Lazure P., 1992, Etude de la dynamique de l'étang de Thau par modèle numérique tridimensionnel, Vie et Milieu, 42, 137-145.

Maritorena S, Morel A. and Gentili B., 1994, Diffuse reflectance of oceanic shallow waters : Influence of water depth on bottom albedo, Limnology and Oceanography, 37, 16891703.

Mazouni N., Gaertner J.M., Deslous-Paoli J.M., Landrein S. and Geringer d’Oedenberg M., 1996, Nutrient and oxygen exchanges at the water-sediment interface in a shellfish farming lagoon (Thau, France), Journal of experimental Marine Biology and Ecology, vol 203, 91-113.

Mazouni N., Gaertner J.M., Deslous-Paoli J.M., Landrein S. and Geringer d’Oedenberg M., 1998, Influence of oyster culture on the water column characteristics in a coastal lagoon (Thau, France), Hydrobiologia, 373/374, 149-156.

Millet B., 1989, Fonctionnement hydrodynamique du basin de Thau, Validation d'un modèle numérique de circulation (programme ECOTHAU), Oceanologica Acta, 12, 37-46.

Morel A., 1988, Optical modelling of the upper ocean in relation to its biogenous matter content, Journal of Geophysical Research, 93, 10747- 10768.

Neveux J. and Lantoine F., 1993, Spectrofluorimetric assay of chlorophylls and phaepigments using the least squares approximation techniques, Deep-Sea Research, 40, 1747-1765.

Pringault O., Kuhl M., De Wit R. and Caumette P., 1998. Growth of green sulphur bacteria in experimental benthic oxygen, sulphide, $\mathrm{pH}$ and light gradients. Microbiology-UK, 144, 1051-1061. 
Rowe G.T., Seasonal hypoxia in the bottom water off the Mississippi river delta, 2001, Journal of Environment Quality, 30, 281-290

Santer R. and Schmechtig S., 2000, Adjacency Effects on Water Surfaces: Primary Scattering Approximation and Sensitivity Study, Appl. Opt. 39, 361-375

Sathyendranath S., Prieur L. and Morel A., 1989, A three-component model of ocean colour and its application to remote sensing of phytoplankton pigments in coastal waters, International Journal of Remote Sensing, 10, 1373-1394.

Schiller H. and Doerffer R., 1999, Neural network for emulation of an inverse modeloperational derivation of case II water properties from MERIS data, International Journal of Remote Sensing, 20, 1735-1746.

Souchu P., Gasc A., Collos Y., Vaquer A., Tournier H., Bibent B. and Deslous-Paoli JM, 1998. Biogeochemical aspects of bottom anoxia in a Mediterranean lagoon (Thau, France). Marine Ecology-Progress Series, 164, 135-146.

Weeks S. J., Currie B., and Bakun A., 2002, Massive emissions of toxic gas in the Atlantic. Nature, 415, 493-494.

Vos R.J., Hakvoort J.H.M., Jordans, R.W.J. and Ibelings B.W., 2003, Multiplatform optical monitoring of eutrophication in temporally and spatially variable lakes, the Science of the Total Environment, 312, 221-243

Zilioli E. and Brivio P.A., 1997, The satellite derived optical information for the comparative assessment of lacustrine water quality, the Science of the Total Environment, 196, 229245 


\section{List of Table and Figure Captions}

Table I : $\quad$ MERIS image database. $\mathrm{X}$ represents an available image

Table II : $\quad$ Thresholds applied to chlorophyll products provided by MERIS level 2 .

Fig. 1 : $\quad$ Location of ground measurements during the anoxic crisis in summer 2003, 2006 and seasonal survey carried out every 2 months

Fig. 2 : $\quad$ Relationship between chl2 and chlorophyll water measurements

Fig. 3 : $\quad$ Temporal evolution of chl2 estimated and measured between August 2002 and August 2006 in the Thau lagoon .

Fig. 4 : $\quad$ Eutrophication map derived from chl2 corrected in the Thau lagoon .

a) winter (23 January 2003), b) spring (17 April 2003),

c) summer (22 August 2003), d) autumn (25 October 2003)

Fig. 5: Colour composites of the 3 reflectance images of MERIS acquired during summer 2003 on the lagoon of Thau.

Fig.6 : Comparison of 2 spectral reflectance profiles in the lagoon : "milky turquoise” spot and safe lagoon on 22 August 2003 (fig. 5)

Fig. 7 : $\quad$ Correlation between chl2 corrected and \% of oxygen at $1 \mathrm{~m}$ depth for the Mèze area in summers 2003 (9 dates between 5 July and 19 September 2003) and 2006 (5 dates between 10 July and 29 July 2006). 
Table I : $\quad$ MERIS image database, $\mathrm{X}$ represents an available image

\begin{tabular}{|c|c|c|c|c|c|c|c|c|c|c|c|c|}
\hline & Jan. & Feb. & Mar. & Apr. & May & Jun. & Jul. & Aug. & Sep. & Oct. & Nov. & Dec \\
\hline 2002 & & & & & & & & X & & X & & \\
\hline 2003 & $\mathrm{XX}$ & $\mathrm{X}$ & & $\mathrm{X}$ & $\mathrm{X}$ & $\mathrm{X}$ & $\mathrm{XXX}$ & $\mathrm{XXXX}$ & $\mathrm{XX}$ & $\mathrm{X}$ & $\mathrm{X}$ & $\mathrm{XX}$ \\
\hline $\mathbf{2 0 0 4}$ & & $\mathrm{X}$ & & $\mathrm{X}$ & $\mathrm{X}$ & $\mathrm{X}$ & $\mathrm{XX}$ & $\mathrm{X}$ & & $\mathrm{X}$ & & \\
\hline $\mathbf{2 0 0 5}$ & $\mathrm{X}$ & $\mathrm{X}$ & $\mathrm{X}$ & $\mathrm{X}$ & $\mathrm{X}$ & $\mathrm{X}$ & $\mathrm{X}$ & $\mathrm{X}$ & $\mathrm{X}$ & & $\mathrm{X}$ & \\
\hline $\mathbf{2 0 0 6}$ & $\mathrm{X}$ & $\mathrm{X}$ & $\mathrm{X}$ & $\mathrm{X}$ & $\mathrm{X}$ & $\mathrm{X}$ & $\mathrm{XXXXX}$ & $\mathrm{X}$ & $\mathrm{X}$ & $\mathrm{X}$ & & \\
\hline
\end{tabular}


Table II : $\quad$ Thresholds applied to chlorophyll products provided by MERIS level 2

\begin{tabular}{|c|c|c|c|c|c|}
\hline $\begin{array}{l}\text { Eutrophication } \\
\text { Status }\end{array}$ & Very good & Good & Medium & Poor & Bad \\
\hline $\operatorname{chl} a\left(\mathrm{mg} \mathrm{m}^{-3}\right)$ & $0-5$ & $5-7$ & $7-10$ & $10-20$ & $>20$ \\
\hline
\end{tabular}




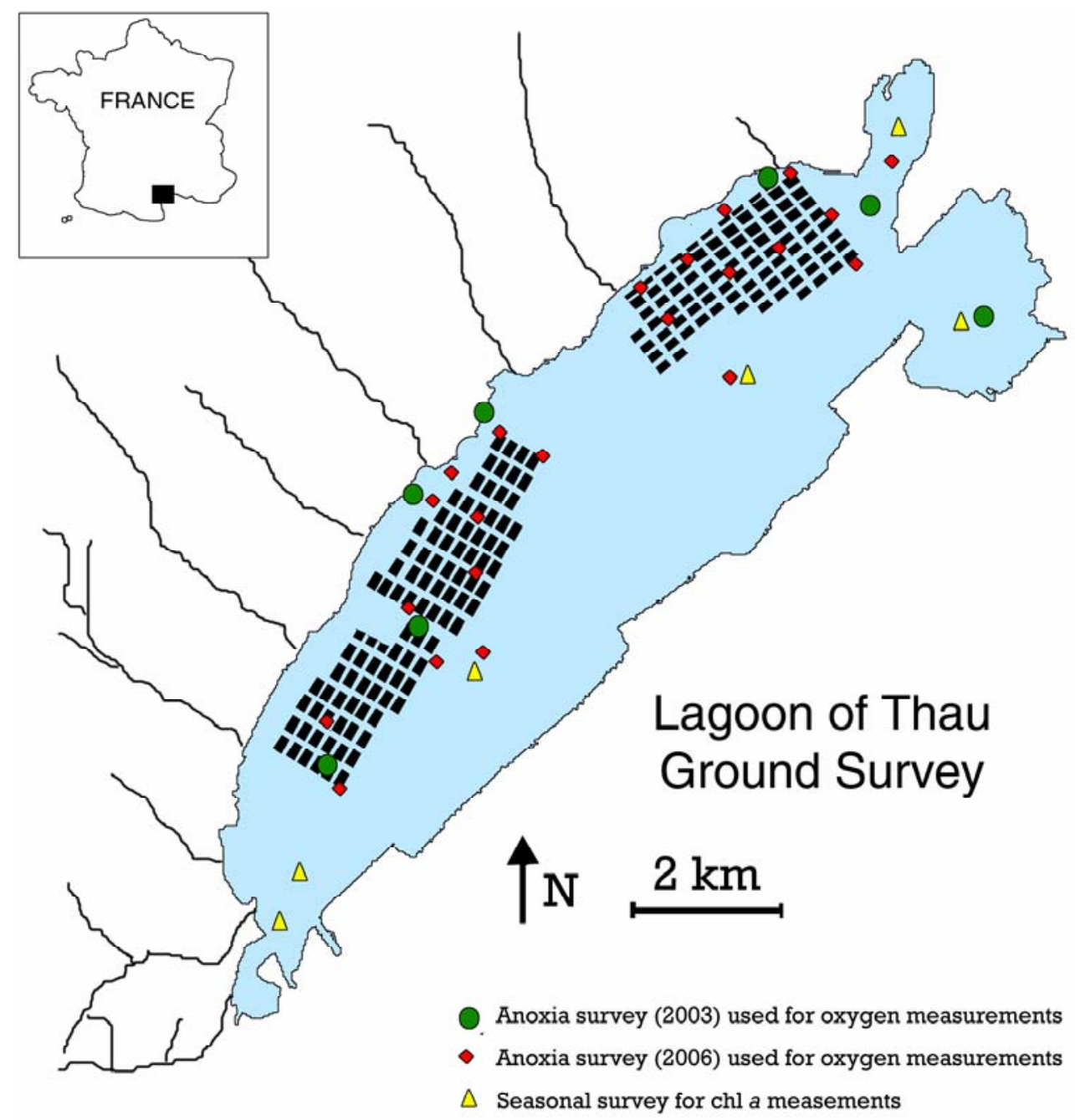

Fig. 1 : Location of ground measurements during the anoxic crises in summers 2003, 2006 and seasonal survey carried out every 2 months 
- Measurements between 19 August 2002 and 19 July 2004

- Measurements between 23 August 2004 and 21 August 2006

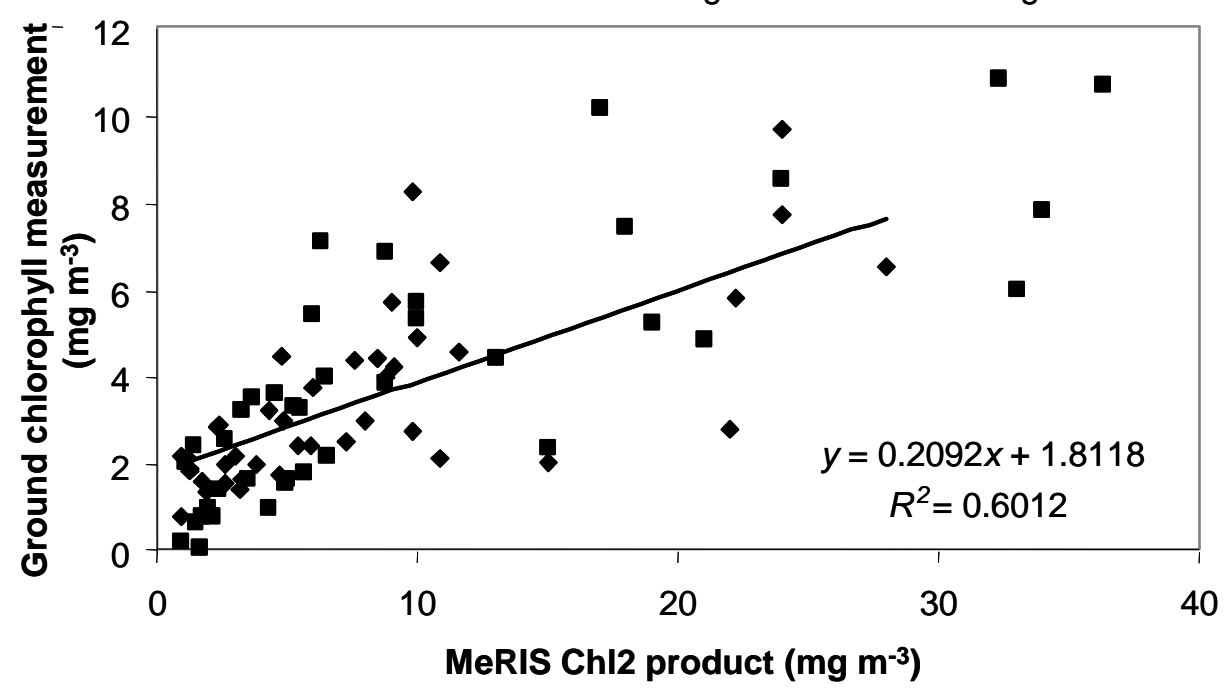

Fig. 2 : Relationship between chl2 and chlorophyll measurements 


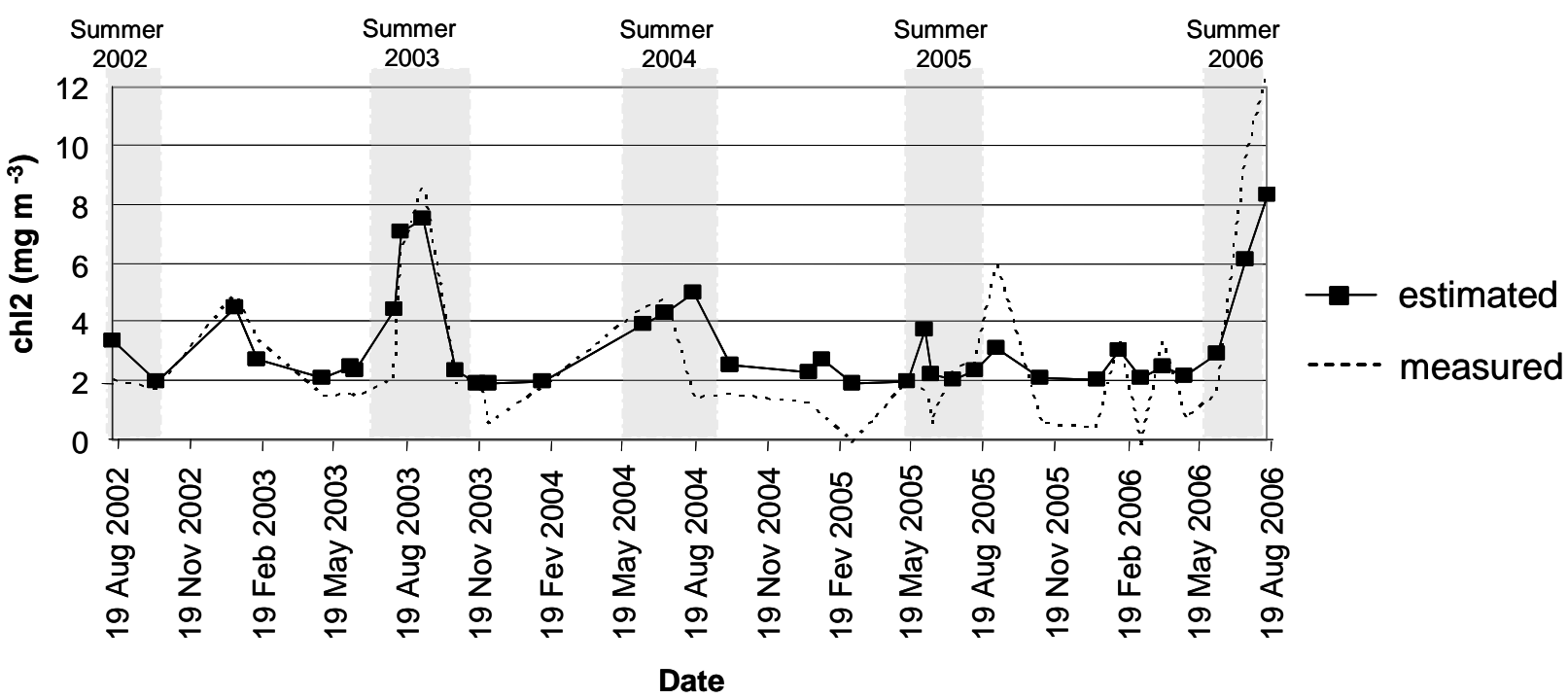

Fig. 3 : Temporal evolution of chl2 estimated and measured between August 2002 and August 2006 in the Thau lagoon . 


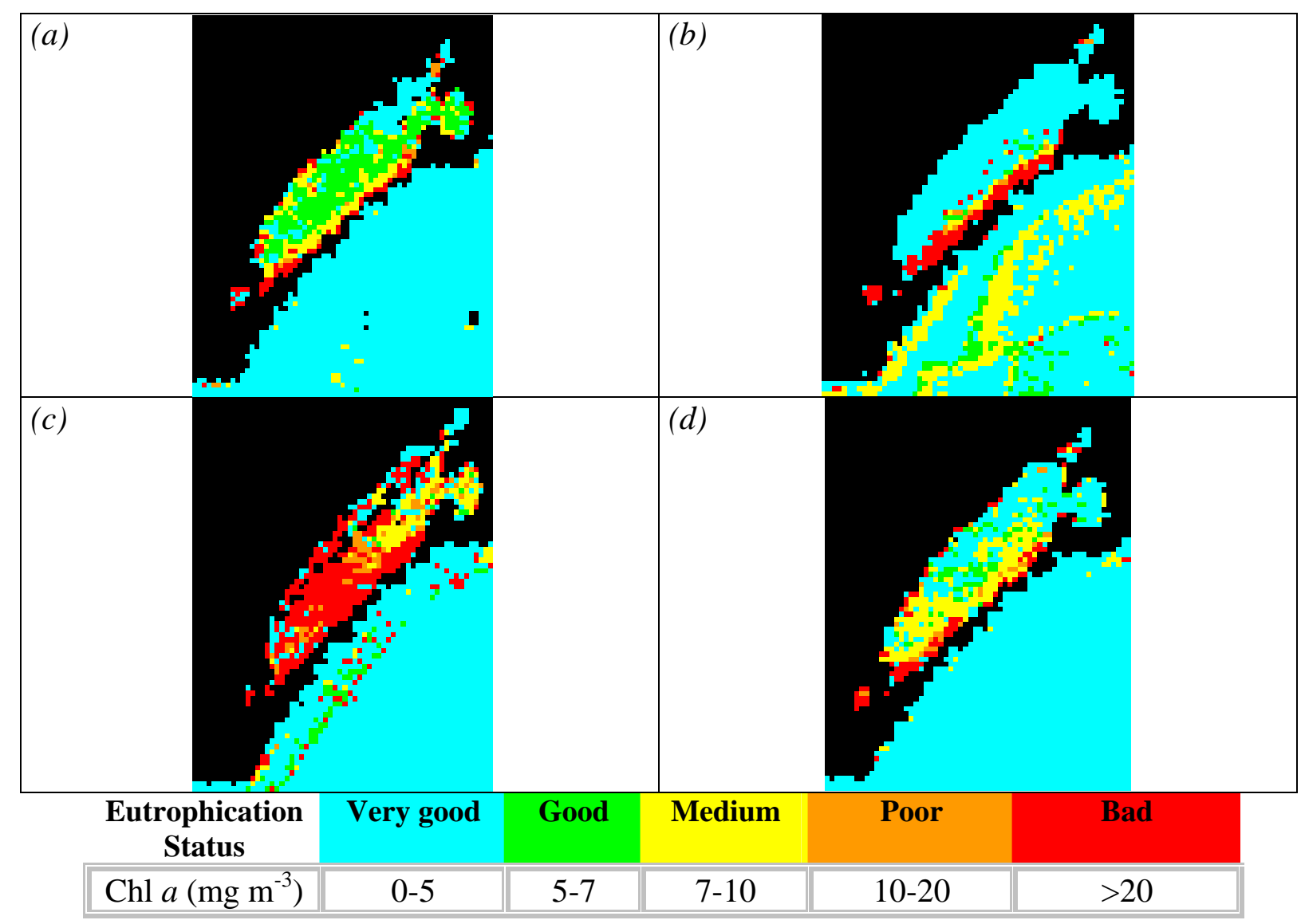

Fig. 4 : Eutrophication map derived from chl2 corrected in the Thau lagoon .

(a) winter (23 January 2003), (b) spring (17 April 2003),

(c) summer (22 August 2003), (d) autumn (10 October 2003) 


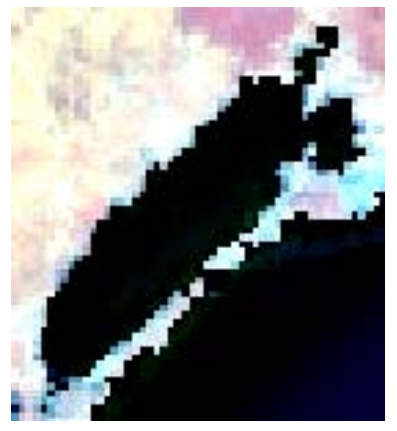

9 Aug 2003

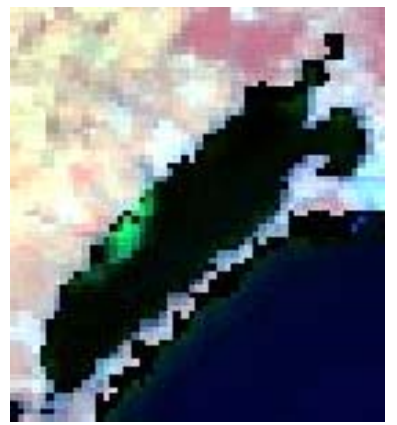

22 Aug 2003

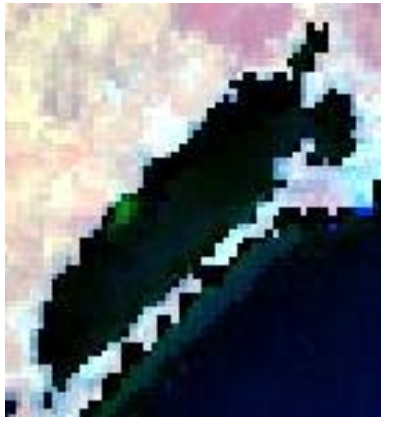

12 Aug 2003

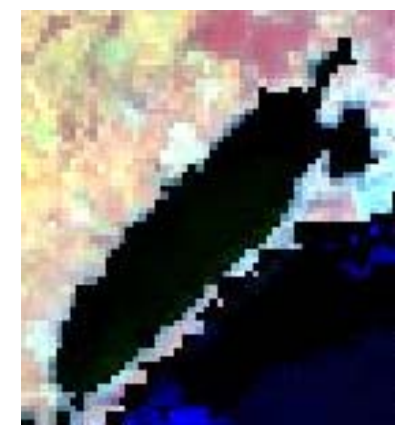

13 Sept 2003

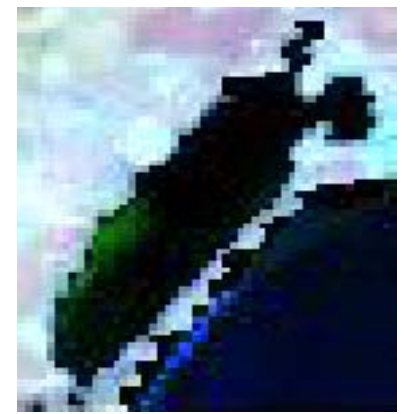

19 Aug 2003

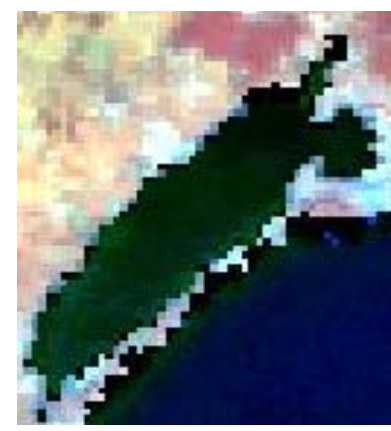

19 Sept 2003

Fig. 5: Colour composites of the 3 reflectance images of MERIS acquired during summer 2003 on the Thau lagoon . 


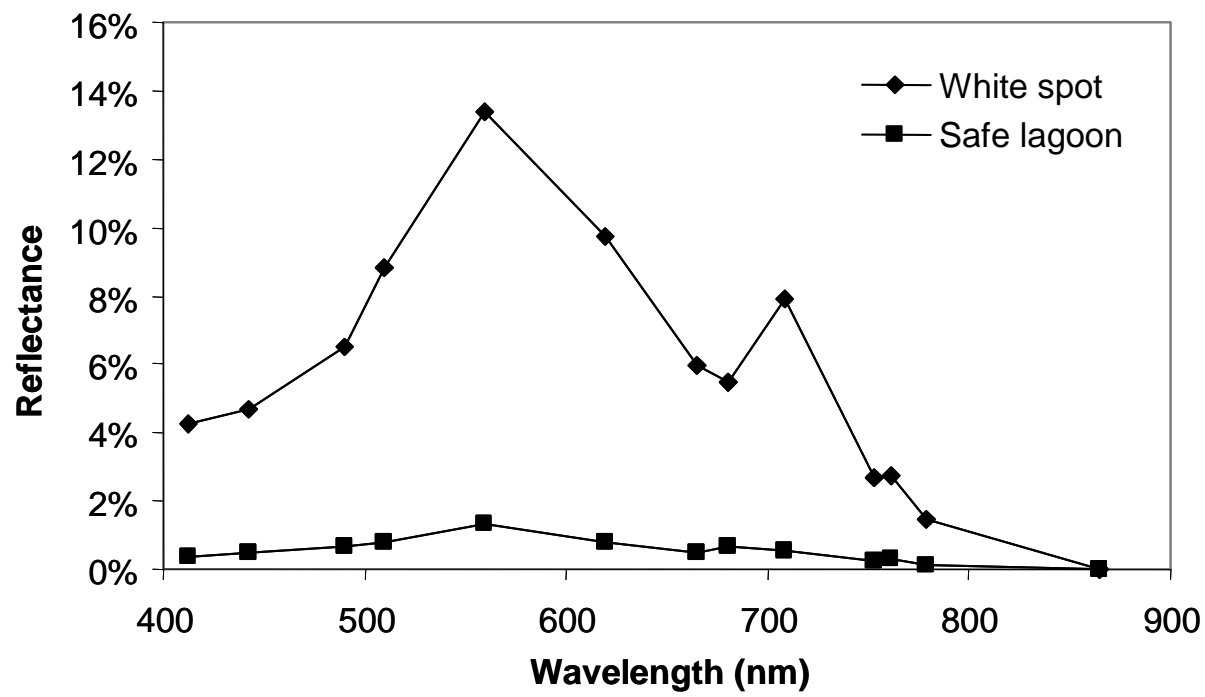

Fig. 6: Comparison of 2 spectral reflectance profiles in the lagoon : "milky turquoise" spot and safe lagoon on 22 August 2003 (fig. 5) 


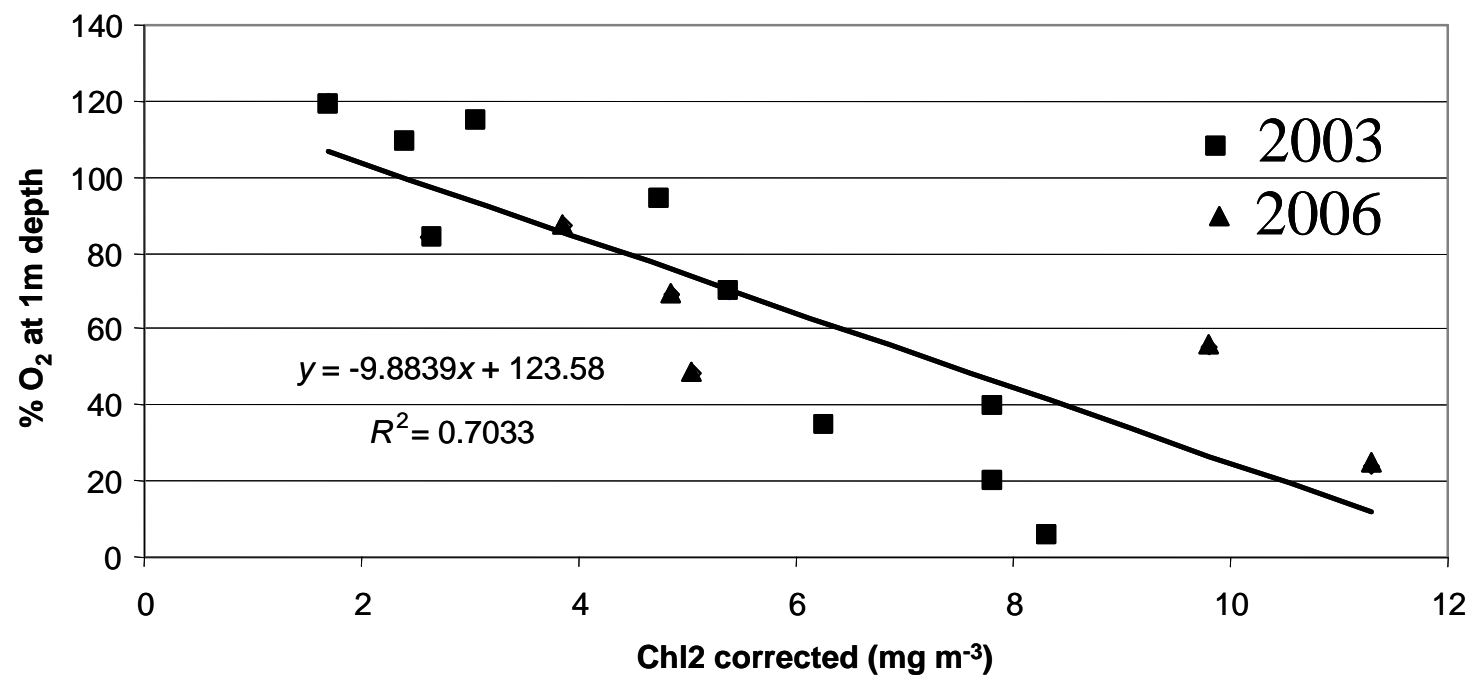

Fig. 7: Correlation between chl2 corrected and \% of oxygen at $1 \mathrm{~m}$ depth

for the Mèze area in summers 2003 (9 dates between 5 July and 19 September 2003) and 2006 (5 dates between 10 July and 29 July 2006). 